\title{
Evaluation of Oryza coarctata candidate reference genes under different abiotic stresses
}

\author{
S. CHOWRASIA ${ }^{1}$, H. KAUR ${ }^{1}$, A. MUJIB ${ }^{2}$, and T.K. MONDAL ${ }^{1 *}$ \\ ICAR-National Research Centre on Plant Biotechnology, IARI Campus, Pusa, New Delhi-110012, India ${ }^{1}$ \\ Department of Botany, Jamia Hamdard, New Delhi-110062, India ${ }^{2}$
}

\begin{abstract}
Oryza coarctata Roxb. is a wild halophytic species found mostly on South Asian seashore. It can tolerate salinity up to $4 \mathrm{~S} \mathrm{~m}^{-1}$, which is equivalent to $479 \mathrm{mM} \mathrm{NaCl}$. This species has unique morphological, anatomical, as well as physiological adaptations, which helps it to survive under high salinity and submerged conditions. Thus, it is considered to be a reservoir of salinity and submergence tolerance genes. For quantification of gene expressions, it is necessary to identify stable reference genes and validate stress responsive genes by real time quantitative PCR. The present study deals with the expression analyses of eight candidate reference genes, namely, ubiquitin 2 , histone 3, $\beta$-tubulin, $\alpha$-tubulin, glyceraldehyde-3-phosphate dehydrogenase, eukaryotic initiation factor 4- $\alpha$ (eIF4- $\alpha$ ), cyclophilin, and actin $(A C T)$ under different abiotic stresses such as salinity, cold, drought, heat, submergence, submergence with saline water (dual stress), and abscisic acid treatment. The four different statistical algorithms, namely, Bestkeeper, NormFinder, geNorm, and RefFinder were used to rank the genes in order of stability. The analysis revealed that $A C T$ and $e I F 4-\alpha$ were the two most stable reference genes, which was further validated by determining the expressions of two well-known stress responsive genes alcohol dehydrogenase and dehydration responsive element binding protein $2 A$ under submergence and drought stress, respectively. This study is the first report to analyse the reference genes for $O$. coarctata.
\end{abstract}

Additional key words: abscisic acid, cold, drought, gene expression, halophyte, heat, salinity, submergence.

\section{Introduction}

Being sessile, plants encounter many abiotic stresses during their life cycles. Thus, several tolerance mechanisms have been evolved to encounter such stresses. Drought, salinity, submergence, and high as well as low temperatures are important abiotic stresses, which negatively affect the growth of plants. Gene expression studies are important to understand the complex molecular mechanisms involving signal transduction, development, and metabolic pathways in plants. Nowadays, major techniques, such as microarray, northern hybridization, real time quantitative polymerase chain reaction (qPCR) are widely used to study gene expression. Among these, real time qPCR is used extensively for its better reproducibility and high sensitivity (Bustin 2002). Quantitative gene expression can be analysed by two different modules, either by an absolute quantification method or by a relative quantification method. The absolute quantification is used to quantify the exact transcript expression values based on a standard curve built from known transcript concentrations, whereas the relative quantification calculates fold change values of target genes which in turn utilizes some reference genes for normalization.

However, for any transcript profiling and expression studies through real time qPCR under particular conditions, it is necessary to identify the most stable reference genes. Most of the previously used reference genes were housekeeping genes known to be involved in basic cellular functions, thus assumed to be stable during various developmental stages. But recent studies demonstrated that expressions of these reference genes are not stable under various abiotic stresses (Singh et al. 2015, Shivhare and Lata 2016). Thus, it is imperative to

\footnotetext{
Submitted 6 May 2018, last revision 16 February 2019, accepted 19 February 2019.

Abbreviations: ABA - abscisic acid; $A C T$ - actin; $A D H$ - alcohol dehydrogenase; $\mathrm{Cq}$ - quantitative cycle; CV- coefficient of variance; $C Y P$ - cyclophilin; DREB2A - dehydration responsive element binding protein 2A; EC - electrical conductivity; eIF4- $\alpha$ - eukaryotic initiation factor 4- $\alpha$; GAPDH - glyceraldehyde-3-phosphate dehydrogenase; $H 3$ - histone 3; qPCR- quantitative polymerase chain reaction; SD - standard deviation; SV - expression stability value; $\alpha$-Tub - $\alpha$-tubulin; $\beta$-Tub - $\beta$-tubulin; UBQ2 - ubiquitin 2.

Acknowledgements: SC and HK acknowledge the financial support from the Council of Scientific \& Industrial Research and DST, India, respectively. We are grateful to the Director, ICAR- NRCPB, for providing the facilities to conduct experiments.

* Corresponding author; e-mail: mondaltk@yahoo.com
} 
have well-studied internal control genes for real time qPCR data normalization to correct variations associated with experimental processes accurately such as sampling, the volume of starting materials taken for RNA extraction, enzymatic efficiencies, and differential expressions of genes across tissues (Expósito-Rodríguez et al. 2008, Udvardi et al. 2008).

Oryza coarctata is a wild halophyte, which is found in the South-East coastal region including the Sunderbans delta in India. It can flower and set seeds even under high salinity (electrical conductivity up to $4 \mathrm{~S} \mathrm{~m}^{-1}$ ) and under submergence (Bal and Dutt 1986, Chowrasia et al. 2018). During its growth in coastal regions, this plant experiences the lunar tide for every $12 \mathrm{~h}$ and is almost submerged in salt water. On the other hand, Oryza sativa L., the most important cereal crop world-wide, is a glycophytic species. Only few salt tolerant genotypes of rice are available (Thomson et al. 2010, Linh et al. 2012, Hoque et al. 2015). Therefore, $O$. coarctata would serve as an unexplored source of resistant alleles for salinity tolerance. However, to study stress responsive gene expression in this wild species using real time qPCR, there is a need to establish stable reference genes.

Therefore, the present study is focused on identification and validation of stable and well expressed reference genes under different abiotic stresses, such as heat, cold, drought, salinity, submergence and submergence with saline water (dual stress), as well as abscisic acid (ABA) treatments, which will help in normalization of target gene expressions in this plant. Based on published literature, eight candidate genes, namely, ubiquitin 2 (UBQ2), histone 3 (H3), beta tubulin $(\beta-T u b)$, alpha tubulin $(\alpha-T u b)$, glyceraldehyde-3phosphate dehydrogenase (GAPDH), eukaryotic initiation factor 4-alpha (eIF4- $\alpha)$, cyclophilin (CYP) and actin $(A C T)$ were selected for this purpose.

\section{Materials and methods}

Plants and treatments: Young seedlings of $O$. coarctata were grown in soil and kept in a glasshouse under a $16 \mathrm{~h}$ photoperiod, an irradiance of $56 \mu \mathrm{mol} \mathrm{m} \mathrm{m}^{-2} \mathrm{~s}^{-1}$, day/ night temperatures of $25 / 16{ }^{\circ} \mathrm{C}$, and a relative humidity of $60-70 \%$. Two-month-old seedlings were exposed to various kinds of stresses. For cold and heat stresses, plants were subjected to temperatures $4 \pm 1{ }^{\circ} \mathrm{C}$ and $42 \pm 1{ }^{\circ} \mathrm{C}$, respectively. Leaf samples were collected after $0,6,12,24$, and 48 h. Drought treatment was imposed by withdrawing water for $8 \mathrm{~d}$ so that to bring a residual soil moisture content of $13.22 \%$ (DeAngelis 2007), and then leaf samples were collected after $0,6,12,24$, and $48 \mathrm{~h}$. For salinity stress, plants were irrigated with $450 \mathrm{mM} \mathrm{NaCl}$ [electrical conductivity (EC) of $3.6 \mathrm{~S} \mathrm{~m}^{-1}$ ] every alternate day (Mondal et al. 2015), and samples were collected after $0,24,48,72$, and $96 \mathrm{~h}$. Leaves were also treated with $100 \mu \mathrm{M}$ ABA (Singh et al. 2015), and samples were collected after $0,1,2,6,12$, and $24 \mathrm{~h}$. Submergence stress and dual stress (a salinized water with EC of $3.6 \mathrm{~S} \mathrm{~m}^{-1}$ ) were given to plants, and samples were collected after 0 , $6,12,24,48$, and $72 \mathrm{~h}$. All the treated and control samples were immediately frozen and stored at $-80{ }^{\circ} \mathrm{C}$ until RNA extraction. Two biological replicates were taken for each stress treatment.

Extraction of RNA and cDNA preparation: The total RNA from leaf samples (100 mg) was extracted by using a Trizol reagent (Invitrogen, Carlsbad, USA) as per the manufacturer's protocol, and genomic DNA was removed by DNase I treatment (Thermo Fisher Scientific, San Jose, USA). Purified RNA samples were then quantified, and RNA integrity was determined by electrophoresis in a $2 \%(\mathrm{~m} / \mathrm{v})$ formaldehyde-agarose gel. The synthesis of cDNA was performed by using a Verso cDNA synthesis kit (Thermo Fisher Scientific), where the total RNA of $1 \mu \mathrm{g}$ was used for a final reaction volume of $0.02 \mathrm{~cm}^{3}$ and stored at $-20^{\circ} \mathrm{C}$.

Candidate reference gene identifications and real time qPCR analysis: Eight commonly used reference genes, namely, UBQ2, H3, $\beta$-Tub, $\alpha-T u b, G A P D H, e I F 4-\alpha$, $C Y P$, and $A C T$ were selected from previous studies (Table 1 Suppl.). All gene specific primers were designed manually by employing the Vector NTI software (Lu and Moriyama 2004), and details of gene specific primer sequences are provided in Table 1 Suppl. All the cDNA samples were diluted 40 times, amplified with each gene specific primers, and in order to confirm gene identity, the amplified products were sequenced.

A reaction mixture for real time qPCR contained $1 \mathrm{~mm}^{3}$ of diluted cDNA, 10 pmol each gene specific forward and reverse primers, and $5 \mathrm{~mm}^{3}$ of $2 \times$ Power $S Y B R^{\mathrm{TM}}$ Green PCR Master Mix (Thermo Fisher Scientific) in a total reaction volume of $10 \mathrm{~mm}^{3}$. All the reactions were carried out in a Light Cycler 480 II (Roche Molecular Diagnostics, USA) with cycling conditions as follows: a pre-amplification step for one cycle at $95{ }^{\circ} \mathrm{C}$ for $5 \mathrm{~min}$, amplification at $95{ }^{\circ} \mathrm{C}$ for $15 \mathrm{~s}$, annealing at $59-63{ }^{\circ} \mathrm{C}$ for $15 \mathrm{~s}$, and extension at $72{ }^{\circ} \mathrm{C}$ for $30 \mathrm{~s}$ for 40 cycles. Melting curves were determined by using default parameters to check product specificity through a stepwise increase in a melting temperature from 60 to $95{ }^{\circ} \mathrm{C}$. The PCR amplification efficiency (E) and regression coefficient $\left(\mathrm{R}^{2}\right)$ were determined for each of the designed primer sets by using serial dilutions $\left(10^{0}, 10^{-1}, 10^{-2}\right.$, and $\left.10^{-3}\right)$ of cDNA and an amplification curve slope was calculated by the Pfaffl efficiency equation, $E=10^{(-1 / \text { slope })}(3.6 \geq$ slope $\geq 3.1)$ (Pfaffl 2001).

Statistical analyses of reference gene expressions and validation: Expression stability orders for eight selected reference genes were determined from quantification cycle $(\mathrm{Cq})$ or threshold cycle $(\mathrm{Ct})$ values through commonly used statistical and advanced algorithms such as BestKeeper (Pfaffl et al. 2004), NormFinder (Andersen et al. 2004), geNorm (Vandesompele et al. 2002,) and the delta Cq method (Silver et al. 2006). In geNorm and NormFinder, relative quantification values were used. Relative expressions were determined from mean $\mathrm{Cq}$ values through the $2^{-\Delta \Delta C q}$ formula (Schmittgen and Livak 2008). Furthermore, geNorm was used for determination of the 
Table 1. Means and standard deviations of threshold cycle $(\mathrm{Ct})$ values of studied reference genes, namely ubiquitin 2 (UBQ2), histone 3 (H3), $\beta$-tubulin ( $\beta$-Tub), $\boldsymbol{\alpha}$-tubulin ( $\alpha$-Tub), glyceraldehyde-3-phosphate dehydrogenase (GAPDH), eukaryotic initiation factor 4-alpha (eIF4- $\alpha)$, cyclophilin $(C Y P)$, and actin $(A C T)$ in Oryza coarctata under different abiotic stresses such as cold $\left(4 \pm 1{ }^{\circ} \mathrm{C}\right)$, heat $\left(42 \pm 1{ }^{\circ} \mathrm{C}\right)$, drought (withdrawing water for $8 \mathrm{~d}$ ), salinity $(450 \mathrm{mM} \mathrm{NaCl})$, abscisic acid (ABA, $100 \mu \mathrm{M})$, submergence, and saline water $(450 \mathrm{mM}$ $\mathrm{NaCl})$ with submergence (dual stress); (* represents the less variable standard deviations).

\begin{tabular}{llllllll}
\hline Gene & Cold & Heat & Drought & Salinity & Submergence & ABA treatment & Dual stress \\
\hline UBQ2 & $31.01 \pm 0.92$ & $30.83 \pm 1.28$ & $31.06 \pm 1.81$ & $31.50 \pm 1.34$ & $29.36 \pm 1.61$ & $29.04 \pm 2.3$ & $29.62 \pm 1.9$ \\
H3 & $25.54 \pm 1.40$ & $27.15 \pm 2.89$ & $25.20 \pm 1.14$ & $25.56 \pm 1.42$ & $26.08 \pm 1.23$ & $25.74 \pm 1.22$ & $24.57 \pm 1.57$ \\
$\alpha-$ Tub & $28.55 \pm 1.28$ & $31.94 \pm 1.45$ & $29.41 \pm 0.85$ & $29.98 \pm 1.95$ & $31.03 \pm 1.39$ & $34.59 \pm 1.92$ & $29.34 \pm 1.18$ \\
$\beta-$ Tub & $31.05 \pm 1.39$ & $33.04 \pm 1.4$ & $30.38 \pm 0.81$ & $31.29 \pm 1.23$ & $31.72 \pm 0.73^{*}$ & $34.35 \pm 1.09$ & $30.53 \pm 0.74$ \\
GAPDH & $35.58 \pm 1.5$ & $34.58 \pm 1.14$ & $34.17 \pm 1.49$ & $30.89 \pm 1.53$ & $33.82 \pm 1.67$ & $32.57 \pm 2.17$ & $34.43 \pm 1.41$ \\
eIF4- $\alpha$ & $27.43 \pm 0.52$ & $27.07 \pm 1.26$ & $27.61 \pm 0.53 *$ & $27.58 \pm 0.48$ & $27.67 \pm 1.64$ & $27.72 \pm 1.34$ & $27.33 \pm 0.87$ \\
CYP & $32.59 \pm 1.86$ & $34.41 \pm 1.70$ & $31.29 \pm 0.92$ & $33.01 \pm 2.5$ & $32.55 \pm 1.2$ & $33.04 \pm 1.77$ & $31.43 \pm 1.85$ \\
ACT & $26.60 \pm 0.49^{*}$ & $25.79 \pm 0.71^{*}$ & $25.42 \pm 0.93$ & $25.80 \pm 0.20^{*}$ & $26.22 \pm 1.18$ & $26.58 \pm 0.56^{*}$ & $26.01 \pm 0.29^{*}$ \\
\hline
\end{tabular}

optimal number of candidate reference genes required for real time qPCR normalization by calculating the pairwise variation $\left(\mathrm{V}_{\mathrm{n}} / \mathrm{V}_{\mathrm{n}+1}, \mathrm{n}\right.$ - a reference gene number used for normalization). If the average pairwise variation among the sequential normalization factors $(\mathrm{NF}), \mathrm{NF}_{\mathrm{n}}$ and $\mathrm{NF}_{\mathrm{n}+1}$, are less than 0.15 , then added reference genes provide significantly improved normalization in comparison to a single reference gene. An average pairwise expression ratio (an $\mathrm{M}$ value) was also determined by geNorm, and the threshold value of $\mathrm{M}$ should be less than 1.5 for determination of stable reference genes (Vandesompele et al. 2002). In BestKeeper and the delta Cq method, the means of $\mathrm{Cq}$ values were analyzed directly.

In order to validate the studied reference genes, the relative expression values of two known stress responsive genes, such as alcohol dehydrogenase (ADH) (Garg et al. 2013 ) and dehydration responsive element binding protein $2 A$ (DREB2A) (Sakuma et al. 2006), were determined by normalizing with the eight selected reference genes under submergence and drought stress, respectively.

Two biological replicates each with two independent technical replicates were analysed for seven different stress treatments. Statistical significance was determined using the Student $t$-test (at $\alpha=0.05$ and 0.01 ).

\section{Results}

The sequences of reference genes $\alpha-T u b, \beta-T u b, G A P D H$, eIF4- $\alpha, C Y P$, and $A C T$ of $O$. coarctata were not available in the NCBI GenBank at the time of this study, therefore gene specific primers were manually designed using $O$. sativa as a reference genome. Sequencing PCR amplified products was done and submitted to the NCBI (Table 1 Suppl.). The sequence information is provided in Table 2 Suppl. The percentage of identity with rice homologues was determined (Table 3 Suppl.). The $\mathrm{R}^{2}$ and $\mathrm{E}$ values for each primer pair were determined using serial dilutions of the cDNA. The $\mathrm{R}^{2}$ was calculated from the standard curve slope, and it ranged from 0.962 for $\alpha-T u b$ to 0.998 for GAPDH (Table 1 Suppl). Primer amplification efficiencies, i.e., E values varied from $79.93 \%$ for $\alpha$-Tub to $106.47 \%$ for $H 3$. The dissociation curves were analysed by real time qPCR to ascertain the specificity of the primers for a single PCR product. A single peak represented a single amplicon for each of the primer pairs (Fig. 1 Suppl.).

The expressions of the eight reference genes were determined in terms of $\mathrm{Cq}$ values, which were found to be variable under different stresses such as cold, heat, drought, salinity, submergence and the dual stress, and ABA treatment (Fig. 1, Table 1). Higher Cq values represented lesser expressions and vice-versa. The mean $\mathrm{Cq}$ values of eight reference genes varied from 24.57 to 35.58 across the samples. Standard deviation (SD) was determined from the mean Cq values, and SD less than one was found to be least variable. Among all the candidate reference genes, $H 3$ was found to have a maximum expression under most stresses, whereas GAPDH showed a least expression (Table 1). The analysis of SD values reveals that $A C T$ was least variable under all the experimental conditions except in drought

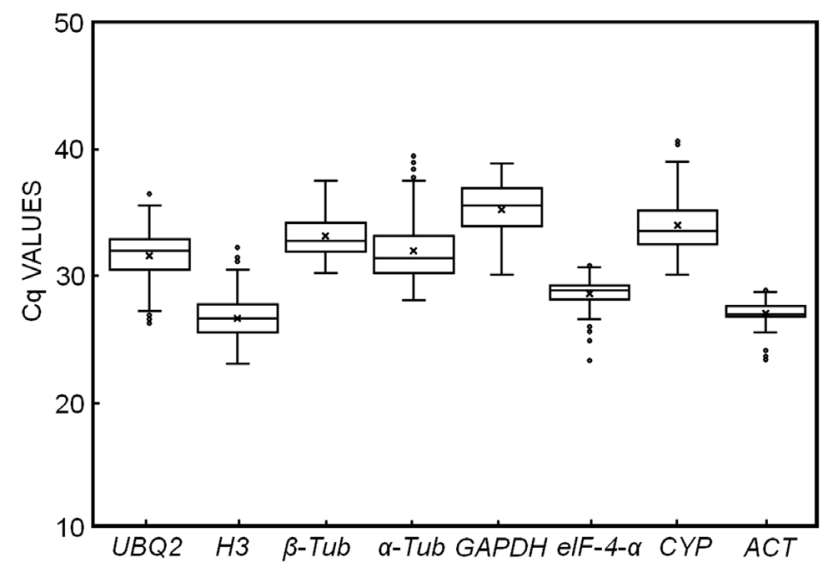

Fig. 1. Quantification cycle $(\mathrm{Cq})$ values represented by boxes; the lines crossing the box represent median values, and the asterisks represent outliers. The top and the bottom are represented by 75 and 25 percentiles, respectively. The whiskers represent 95 percentile confidence intervals. For abbreviations of gene names refer to Table 1 . 
Table 2. Rank orders of eight candidate reference genes from Oryza coarctata under different abiotic stresses in accordance with their standard deviation (SD) and coefficiens of variance (CV) values as determined by BestKeeper. For abbreviations of gene names and applied stresses refer to Table 1 .

\begin{tabular}{|c|c|c|c|c|c|c|c|c|c|c|c|c|}
\hline $\begin{array}{l}\text { Rank } \\
\text { order }\end{array}$ & $\begin{array}{l}\text { Cold } \\
\text { gene }\end{array}$ & SD & $\mathrm{CV}$ & $\begin{array}{l}\text { Heat } \\
\text { Gene }\end{array}$ & SD & $\mathrm{CV}$ & $\begin{array}{l}\text { Drought } \\
\text { gene }\end{array}$ & SD & $\mathrm{CV}$ & $\begin{array}{l}\text { Salinity } \\
\text { Gene }\end{array}$ & SD & $\mathrm{CV}$ \\
\hline 1 & $A C T$ & 0.37 & 1.40 & $A C T$ & 0.51 & 1.97 & $e I F 4-\alpha$ & 0.33 & 1.20 & $A C T$ & 0.12 & 0.47 \\
\hline 2 & $e I F 4-\alpha$ & 0.46 & 1.69 & $C Y P$ & 0.79 & 2.34 & $A C T$ & 0.61 & 2.42 & $e I F 4-\alpha$ & 0.40 & 1.43 \\
\hline 3 & $U B Q 2$ & 0.71 & 2.30 & $U B Q 2$ & 0.90 & 2.90 & $\beta-T u b$ & 0.64 & 2.12 & $U B Q 2$ & 0.96 & 3.05 \\
\hline 4 & $\alpha-T u b$ & 0.95 & 3.33 & $G A P D H$ & 0.95 & 2.76 & $C Y P$ & 0.76 & 2.41 & $\beta-T u b$ & 1.01 & 3.22 \\
\hline 5 & $\beta-T u b$ & 0.99 & 3.19 & eIF4- $\alpha$ & 1.05 & 3.87 & $\alpha-T u b$ & 0.78 & 2.65 & $G A P D H$ & 1.24 & 4.00 \\
\hline 6 & $H 3$ & 1.04 & 4.06 & $\beta-T u b$ & 1.18 & 3.56 & $H 3$ & 1.01 & 3.98 & $\alpha-T u b$ & 1.28 & 4.25 \\
\hline 7 & $G A P D H$ & 1.24 & 3.47 & $\alpha-T u b$ & 1.19 & 3.73 & $G A P D H$ & 1.17 & 3.41 & H3 & 1.32 & 5.11 \\
\hline 8 & $C Y P$ & 1.62 & 4.94 & $H 3$ & 1.43 & 5.35 & $U B Q 2$ & 1.44 & 4.62 & $C Y P$ & 2.10 & 6.35 \\
\hline
\end{tabular}

\begin{tabular}{|c|c|c|c|c|c|c|c|c|c|}
\hline \multirow{2}{*}{$\begin{array}{l}\text { Rank } \\
\text { order }\end{array}$} & \multicolumn{3}{|c|}{ Submergence } & \multicolumn{3}{|c|}{$\mathrm{ABA}$ treatment } & \multicolumn{3}{|c|}{ Dual stress } \\
\hline & gene & SD & $\mathrm{CV}$ & gene & $\mathrm{SD}$ & $\mathrm{CV}$ & Gene & SD & $\mathrm{CV}$ \\
\hline 1 & $\beta-T u b$ & 0.62 & 1.95 & $A C T$ & 0.48 & 1.81 & $A C T$ & 0.26 & 0.99 \\
\hline 2 & $A C T$ & 0.68 & 2.57 & $e I F 4-\alpha$ & 0.98 & 3.51 & $\beta-T u b$ & 0.62 & 2.03 \\
\hline 3 & $C Y P$ & 0.91 & 2.80 & H3 & 1.03 & 3.99 & eIF4- $\alpha$ & 0.69 & 2.52 \\
\hline 4 & $e I F 4-\alpha$ & 0.98 & 3.55 & $\beta-T u b$ & 1.19 & 3.51 & $\alpha-T u b$ & 0.86 & 2.94 \\
\hline 5 & H3 & 1.08 & 4.12 & $C Y P$ & 1.49 & 4.50 & GAPDH & 1.22 & 3.55 \\
\hline 6 & GAPDH & 1.13 & 3.34 & GAPDH & 1.86 & 5.72 & $C Y P$ & 1.32 & 4.19 \\
\hline 7 & $\alpha-T u b$ & 1.15 & 3.71 & $U B Q 2$ & 1.94 & 6.68 & H3 & 1.33 & 5.41 \\
\hline 8 & $U B Q 2$ & 1.20 & 4.09 & $\alpha-T u b$ & 2.05 & 6.11 & $U B Q 2$ & 1.68 & 5.69 \\
\hline
\end{tabular}

Table 3. Rank orders of eight selected reference genes of Oryza coarctata based upon their expression stability value (SV) analysed by NormFinder. For abbreviations of gene names and applied stresses refer to Table 1.

\begin{tabular}{|c|c|c|c|c|c|c|c|c|c|c|c|c|c|c|}
\hline \multirow{2}{*}{$\begin{array}{l}\text { Rank } \\
\text { order }\end{array}$} & \multirow{2}{*}{$\begin{array}{l}\text { Cold } \\
\text { gene }\end{array}$} & \multirow[b]{2}{*}{ SV } & \multirow{2}{*}{$\begin{array}{l}\text { Heat } \\
\text { gene }\end{array}$} & \multirow[b]{2}{*}{ SV } & \multicolumn{2}{|l|}{ Drought } & \multicolumn{2}{|l|}{ Salinity } & \multicolumn{2}{|c|}{ Submergence } & \multicolumn{2}{|c|}{$\mathrm{ABA}$ treatment } & \multicolumn{2}{|c|}{ Dual stress } \\
\hline & & & & & Gene & SV & Gene & SV & gene & SV & gene & SV & Gene & SV \\
\hline 1 & $H 3$ & 0.348 & $A C T$ & 0.511 & $e I F 4-\alpha$ & 0.379 & $A C T$ & 0.477 & $\beta$-Tub & 0.402 & $C Y P$ & 0.698 & $\beta$-Tub & 0.193 \\
\hline 2 & $\alpha-$ Tub & 0.550 & $e I F 4-\alpha$ & 0.759 & $\beta$-Tub & 0.442 & $e I F 4-\alpha$ & 0.509 & $A C T$ & 0.530 & H3 & 0.711 & $e I F 4-\alpha$ & 0.408 \\
\hline 3 & $e I F 4-\alpha$ & 0.583 & $C Y P$ & 0.767 & $A C T$ & 0.443 & $U B Q 2$ & 0.656 & $e I F 4-\alpha$ & 0.571 & $A C T$ & 0.765 & $\alpha$-Tub & 0.483 \\
\hline 4 & $\beta-$ Tub & 0.585 & $\alpha-$ Tub & 0.789 & $\alpha$-Tub & 0.574 & $\beta$-Tub & 0.813 & $\alpha-$ Tub & 0.613 & $\beta$-Tub & 0.830 & GAPDH & 0.682 \\
\hline 5 & $A C T$ & 0.657 & GAPDH & 0.834 & $C Y P$ & 0.576 & $H 3$ & 0.864 & $C Y P$ & 0.641 & GAPDH & 0.937 & $H 3$ & 0.708 \\
\hline 6 & GAPDH & 0.710 & $U B Q 2$ & 0.859 & $H 3$ & 0.651 & $\alpha$-Tub & 0.977 & $H 3$ & 0.708 & $e I F 4-\alpha$ & 1.077 & $U B Q 2$ & 0.730 \\
\hline 7 & $U B Q 2$ & 0.859 & $\beta$-Tub & 0.929 & $G A P D H$ & 0.863 & $G A P D H$ & 1.067 & $G A P D H$ & 0.744 & $U B Q 2$ & 1.159 & $A C T$ & 0.765 \\
\hline 8 & $C Y P$ & 0.910 & $H 3$ & 1.008 & $U B Q 2$ & 0.965 & $C Y P$ & 1.104 & $U B Q 2$ & 0.851 & $\alpha$-Tub & 1.275 & $C Y P$ & 0.775 \\
\hline
\end{tabular}

and submergence stresses, followed by eIF4- $\alpha$ and $\beta$-Tub. The variations in the expressions of the studied reference genes under different experimental sets clearly infer that these reference genes were expressed differentially.

In order to screen out the suitable reference genes for normalization, it was necessary to find out their stability values. The expression stability values of the reference genes can be analysed by several statistical algorithms. The $\mathrm{Cq}$ values of the eight reference genes from seven experimental conditions were analysed individually by each software.

BestKeeper is an excel based tool, which was used to determine the coefficient of variance $(\mathrm{CV})$ and SD of the mean $\mathrm{Cq}$ values. The genes with a higher $\mathrm{SD}$ or $\mathrm{CV}$ were the most unstable ones and vice-versa. The analyses of the $\mathrm{Cq}$ values of the different experimental conditions reveal that $A C T$ and eIF4- $\alpha$ were most stable under cold, drought, and salt stresses, and under ABA treatment (Table 2). However, $\beta$-Tub was highly stable under submergence and dual stresses, and $C Y P$ was most stable under heat and submergence stresses. $U B Q 2$ was determined to be least stable in most of the treatments, and $\alpha-T u b$ was also found to be least stable under heat, submergence, and ABA treatments (Table 2).

NormFinder was employed to calculate the expression stability value (SV) of the eight reference genes depending 
Table 4. Rank orders of eight selected reference genes of Oryza coarctata depending upon their stability expression values calculated by geNorm. M - average pairwise expression ratio. For abbreviations of gene names and applied stresses refer to Table 1.

\begin{tabular}{|c|c|c|c|c|c|c|c|c|c|c|c|c|c|c|}
\hline \multirow{2}{*}{$\begin{array}{l}\text { Rank } \\
\text { order }\end{array}$} & \multirow{2}{*}{$\begin{array}{l}\text { Cold } \\
\text { gene }\end{array}$} & \multirow[b]{2}{*}{ M } & \multirow{2}{*}{$\begin{array}{l}\text { Heat } \\
\text { gene }\end{array}$} & \multirow[b]{2}{*}{ M } & \multicolumn{2}{|c|}{ Drought } & \multicolumn{2}{|l|}{ Salinity } & \multicolumn{2}{|c|}{ Submerge } & \multicolumn{2}{|c|}{$\mathrm{ABA}$ treatment } & \multicolumn{2}{|c|}{ Dual stress } \\
\hline & & & & & Gene & M & gene & M & Gene & M & gene & $\mathrm{M}$ & Gene & M \\
\hline 1 & $\beta$-Tub & 0.800 & $A C T$ & 1.108 & $\beta$-Tub & 0.872 & $A C T$ & 0.964 & $C Y P$ & 1.173 & $A C T$ & 1.318 & $\beta$-Tub & 0.803 \\
\hline 2 & $\alpha-T u b$ & 0.831 & $U B Q 2$ & 1.172 & eIF4- $\alpha$ & 0.885 & $e I F 4-\alpha$ & 0.982 & $H 3$ & 1.203 & $e I F 4-\alpha$ & 1.639 & $e I F 4-\alpha$ & 0.857 \\
\hline 3 & $H 3$ & 0.913 & $e I F 4-\alpha$ & 1.412 & $H 3$ & 0.935 & $U B Q 2$ & 1.292 & $\beta$-Tub & 1.335 & $\beta-$ Tub & 1.808 & $A C T$ & 0.958 \\
\hline 4 & $A C T$ & 1.286 & $C Y P$ & 1.545 & $C Y P$ & 1.080 & $H 3$ & 1.764 & $\alpha-$ Tub & 1.411 & $H 3$ & 1.877 & $\alpha$-Tub & 1.119 \\
\hline 5 & $G A P D H$ & 1.413 & $\beta$-Tub & 1.713 & $A C T$ & 1.367 & $\beta$-Tub & 2.067 & $A C T$ & 1.776 & CYP & 2.134 & $U B Q 2$ & 1.366 \\
\hline 6 & $e I F 4-\alpha$ & 1.531 & $G A P D H$ & 1.809 & $\alpha-$ Tub & 1.515 & $G A P D H$ & 2.319 & $e I F 4-\alpha$ & 1.827 & GAPDH & 2.297 & GAPDH & 1.540 \\
\hline 7 & $U B Q 2$ & 1.590 & $\alpha-$ Tub & 2.044 & $U B Q 2$ & 1.793 & $C Y P$ & 2.686 & $G A P D H$ & 1.927 & $U B Q 2$ & 2.569 & $H 3$ & 1.683 \\
\hline 8 & $C Y P$ & 1.712 & $H 3$ & 2.289 & $G A P D H$ & 1.885 & $\alpha$-Tub & 2.877 & $U B Q^{2}$ & 2.239 & $\alpha$-Tub & 2.847 & CYP & 2.193 \\
\hline
\end{tabular}

upon intra- and inter-group variations among different experimental sets. This programme ranks reference genes depending upon their SV; a lower SV of a gene indicates its greater expression stability and vice-versa (Table 3). Across all the samples, eIF4- $\alpha$ had a low SV under most stresses (cold, heat, drought, salinity, submergence, and dual stress). $A C T$ was also found to be stable under heat, salinity, drought, and submergence. However, in the case of ABA treatment, $C Y P$ and $H 3$ were the most stable reference genes.

The average pairwise expression ratio, the $\mathrm{M}$ value, of the reference genes was analysed by geNorm (Table 4). The threshold value of $\mathrm{M}$ should be less than 1.5 for stable reference genes. Reference genes with higher $\mathrm{M}$ values were less stable. In the present study, $A C T$ was found to be one of the most stable reference gene across all the treatments except submergence (Fig. 2). Additionally, $\beta$-Tub was also shown to be stable under cold, drought, submergence, and dual stresses with $\mathrm{M}$ value $<1.5$. However, GAPDH was found to be consistently unstable under all the stresses except cold and dual stresses with a rather high $\mathrm{M}$ value $(1.809<\mathrm{M}<2.319)$. Similarly, $U B Q 2$ was one of the least stable genes under cold, drought, submergence, and ABA treatments (Table 4).

For all the seven experimental sets except cold and heat stresses, the pairwise variation value of $\mathrm{V}_{2 / 3}$ was less than 0.15 , which indicates that for all the sets, the use of two reference genes is sufficient for accurate normalization of real time qPCR data (Fig. 3).

The average SD values were analysed by the delta $\mathrm{Cq}$ method among different samples and reference genes. From the results, it was observed that $A C T$ followed by $e I F 4-\alpha$ and $\beta$-Tub were most stable in a maximum of experimental sets (Table 4 Suppl.) and $U B Q 2$ was found to be least stable under most stress conditions.

It was clearly observed that the best reference gene for one stress condition may not be suitable for other stress conditions. Therefore, integrating the results from the above described programmes, the best reference genes for individual stress conditions were summarized as: cold $(H 3, \alpha-T u b)$, heat (eIF4- $\alpha, C Y P, A C T)$, drought (eIF4- $\alpha, A C T, \beta$-Tub), salinity (UBQ2, eIF4- $\alpha, A C T), \mathrm{ABA}$ treatment $(A C T, H 3)$, submergence $(A C T, \beta-T u b)$, and dual stress $(\beta-T u b, e I F 4-\alpha)$. Thereby, we can generalize that $A C T$ and IF $4-\alpha$ were the most stable reference genes under most of the treatments, whereas GAPDH and $U B Q 2$ were the least stable reference genes under cold, drought, submergence, and dual stresses.

Further, for validation of the studied reference genes, the two already reported stress inducible genes, viz., $A D H$ under submergence stress and $D R E B 2 A$ under drought stress were normalized with eight selected reference genes, where it was found that results were good when normalized with $A C T$ and $e I F 4-\alpha$ under submergence and drought stresses.

Additionally, the expressions of $A D H$ and $D R E B 2 A$ were normalized with a combination of two genes, i.e., $A C T$ along with $e I F 4-\alpha$, which provided a better normalization of the real time qPCR data in terms of a more statistically significant result as compared to individual reference genes. Conversely, when the expression data of the same stress responsive genes were normalized with least stable reference genes, i.e., GAPDH and $U B Q 2$ individually and in combination, it resulted in statically insignificant normalization (Fig. 4).

\section{Discussion}

Oryza coarctata is a wild rice species, which is able to withstand high salinity and submergence for a certain period of time. Thus, it serves as a great resource for candidate genes for salinity as well as submergence stress tolerances, and it is being considered as a good plant model to study salt stress tolerance (Garg et al. 2013, Mondal et al. 2015). Apart from transcriptomic (Garg et al. 2013) and proteomics studies (Sengupta and Majumder 2009), its genome has been decoded recently (Mondal et al. 2018). Thus, the data can be utilized for identification of stress responsive genes, and real time qPCR analysis is an excellent technique for validation of such stress responsive genes. For an accurate interpretation of real time qPCR data in any particular species, it is necessary to find out stable reference genes in that species. Although several reference genes have been established for various abiotic stress conditions in different plant species (Manoli et al. 


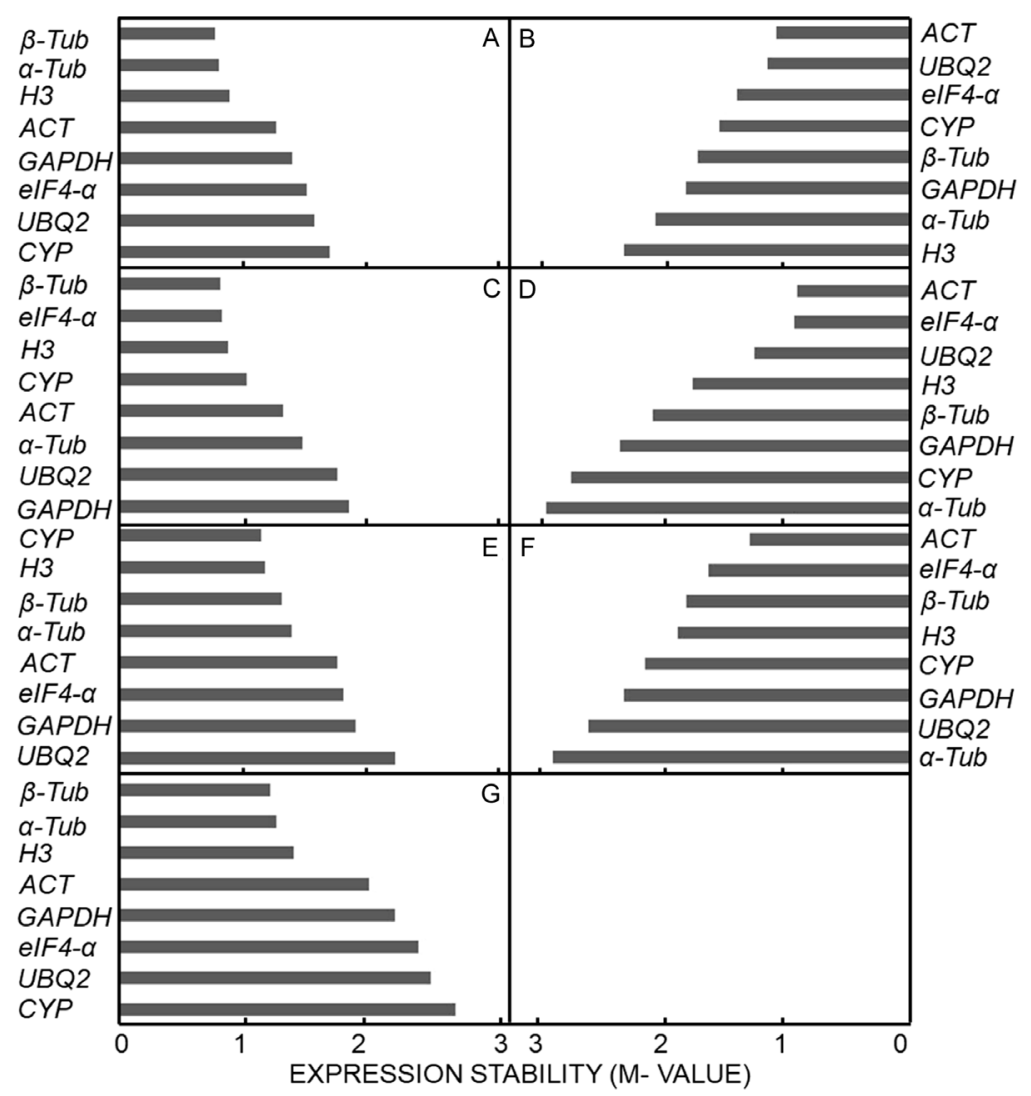

Fig. 2. Expression stability values and rank order of eight candidate reference genes as analysed by geNorm under different abiotic stresses: $A$ - cold, $B$ - heat, $C$ - drought, $D$ - salinity, $E$ - submergence, $F$ - ABA treatment, and $G$ - dual stress. The $x$-axis represents average expression stability (M-value). For abbreviations of gene names and applied stresses refer to Table 1.

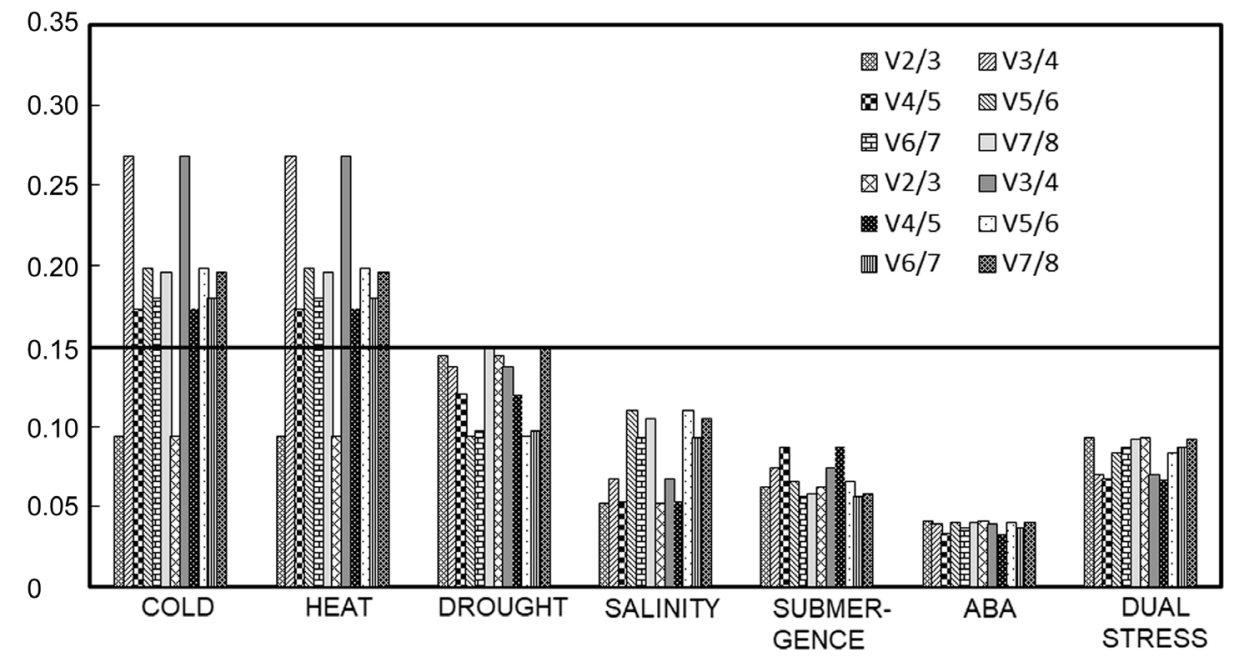

Fig. 3. The average pairwise variations (V) of candidate reference genes determined by geNorm. The $\mathrm{V} \leq 0.15$ is represented by a line, $\mathrm{V}_{2 / 3} \leq 0.15$ indicates that two genes could be used in combination for an effective normalization of target genes. For abbreviations of applied stresses refer to Table 1 .

2012, Wang et al. 2016.), yet it has not been studied in depth for $O$. coarctata.

For this purpose, in the current study, we have examined the expressions of eight potential reference genes by real time qPCR. To analyse the expression data, we have used four statistical algorithms such as BestKeeper, NormFinder, geNorm, and RefFinder. BestKeeper revealed that $A C T$ and $e I F 4-\alpha$ had the lowest $\mathrm{CV}$ and SD values, thus the highest expression stability among all the reference genes in most of the treatments. From NormFinder analysis, it 


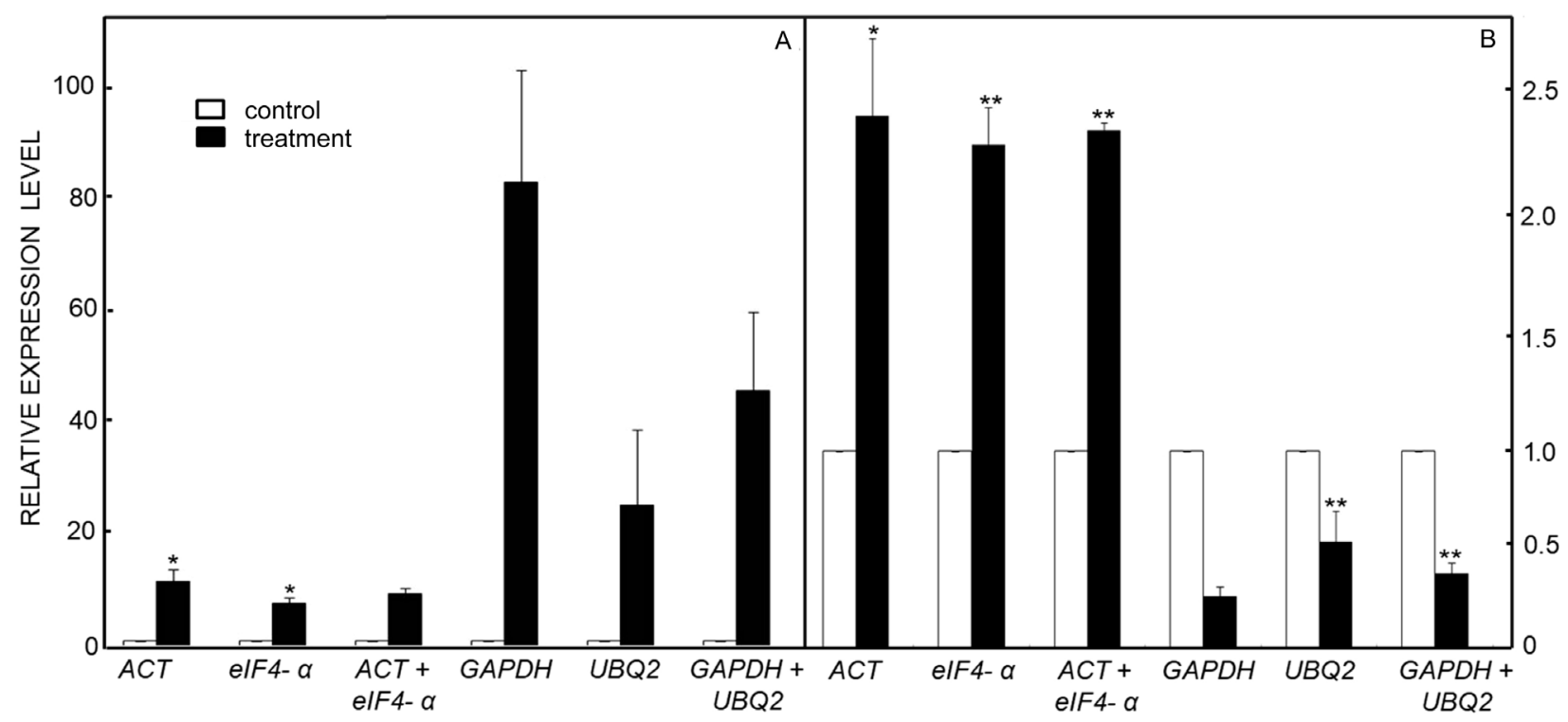

Fig. 4. The validation of the most stable ( $A C T$ and $e I F 4-\alpha)$ and the least stable (GAPDH and UBQ2) reference genes with stress induced genes $A D H(A)$ and $D R E B 2 A(B)$ under submergence and drought, respectively. The values represent means \pm SEs; and the means were compared with $t$ - test $(*-P<0.05, * *-P<0.01)$. For abbreviations of gene name refer to Table 1 .

was found that eIF4- $\alpha$ and $A C T$ had the least SVs, which suggests their most stable expression in all the stress conditions. The M-value of ACT from geNorm analysis was found to be less than 1.5 in six stress treatments out of seven and for eIF4- $\alpha$, the M-value was less than 1.5 in five out of seven experimental sets, which indicates their stability in expression. The comprehensive results from these algorithms show consensus in identifying the top ranked reference genes depending upon their stability values. For example, $A C T$ and $e I F 4-\alpha$ were ranked among the best reference genes across all the software in most of the treatments. Contrastingly, GAPDH and $U B Q 2$ were identified by most softwares as the least stable genes in a maximum number of the experimental sets. These differences in rank order given by different software tools may be due to the individual software sensitivity towards the expressions of co-regulated internal control genes as described in previous reports (Shivhare and Lata 2016, Wu et al. 2016). In several cases, the use of a single reference gene is not sufficient for normalization of real time qPCR data to significant levels, thus the use of more than one reference gene is preferred for data normalization. In the present study, the combination of the two genes in the average pairwise variation is $\mathrm{V}_{2 / 3}<0.15$, which indicates that the two genes can be used in combination for an effective normalization of the target genes.

In addition, the validation of the two most stable reference genes, i.e., eIF4- $\alpha$ and $A C T$, and the two least stable reference genes, i.e., GAPDH and $U B Q 2$, as determined in our study, was also undertaken. For this, the real time qPCR data of the known stress inducible genes, such as $D R E B 2 A$ under dehydration and $A D H$ under submergence, were normalized with $A C T$ and $e I F 4-\alpha$, and in combination of both $(A C T+e I F 4-\alpha)$. Results showed a significant upregulation of the positive stress marker genes during each stress (Sakuma et al. 2006, Garg et al. 2013). In contrast, the normalization of these stress responsive genes with the most variable and least stable reference genes, such as $G A P D H$ and $U B Q 2$ along with their combination $(G A P D H+U B Q 2)$, provided results with a significant disparity, which highlights the need to use stable and well correlated internal control genes for statistically significant real time qPCR data analyses.

\section{Conclusions}

In conclusion, the present study focussed on the identification as well as validation of reference genes under different abiotic stresses in a halophyte species $O$. coarctata. Our findings demonstrate that out of eight studied reference genes, four genes, $H 3$, eIF4- $\alpha, A C T$ and $\beta$-Tub, were the most stable ones for individual stress conditions. However, eIF4- $\alpha$ and ACT showed themselves as the highest ranked reference genes under most of the studied stress conditions. Additionally, the statistical analysis revealed that the use of two reference genes for normalization of real time qPCR data was more reliable than the use of a single reference gene. In conclusion, the present work provides valuable information to facilitate gene expression studies and validation of candidate stress responsive genes in $O$. coarctata.

\section{References}

Andersen, C.L., Jensen, J.L., Ørntoft, T.F.: Normalization of realtime quantitative reverse transcription-PCR data: a modelbased variance estimation approach to identify genes suited for normalization, applied to bladder and colon cancer data condition. - Cancer Res. 64: 5245-5250, 2004.

Bal, A.R., Dutt, S.K.: Mechanism of salt tolerance in wild rice 
(Oryza coarctata Roxb). - Plant Soil 92: 399-404, 1986.

Bustin, S.A.: Quantification of mRNA using real-time reverse transcription PCR (RT-PCR): trends and problems. - J. mol. Endocrinol. 29: 23-39, 2002.

Chowrasia, S., Rawal, H.C., Mazumder, A., Gaikwad, K., Sharma, T.R., Singh, N.K., Mondal, T.K.: Oryza coarctata Roxb. In: Mondal, T.K., Henry, R.J. (ed.): The Wild Oryza Genomes. Pp. 87-104. Springer, Cham 2018.

DeAngelis, K.M.: Measurement of Soil Moisture Content by Gravimetric Method. - American Society of Agronomy, Madison 2007.

Expósito-Rodríguez, M., Borges, A.A., Borges-Pérez, A., Pérez, J.A.: Selection of internal control genes for quantitative realtime RT-PCR studies during tomato development process. BMC Plant Biol. 8: 1-12, 2008

Garg, R., Verma, M., Agrawal, S., Shankar, R., Majee, M., Jain, M.: Deep transcriptome sequencing of wild halophyte rice, Porteresia coarctata, provides novel insights into the salinity and submergence tolerance factors. - DNA Res. 21: 69-84, 2013.

Hoque, A.B.M.Z., Haque, M.A., Sarker, M.R.A., Rahman, M.A.: Marker-assisted introgression of saltol locus into genetic background of BRRI Dhan-49. - Int. J. Biosci. 6: 71-80, 2015.

Linh, L.H., Linh, T.H., Xuan, T.D., Ham, L.H., Ismail, A.M., Khanh, T.D.: Molecular breeding to improve salt tolerance of rice (Oryza sativa L.) in the Red River Delta of Vietnam. - Int. J. Plant Genomics 2012: 949038, 2012.

Lu, G., Moriyama, E.N.: Vector NTI, a balanced all-in-one sequence analysis suite. - Brief Bioinform. 5: 378-388, 2004.

Manoli, A., Sturaro, A., Trevisan, S., Quaggiotti, S., Nonis, A.: Evaluation of candidate reference genes for qPCR in maize. Plant Physiol. J. 169: 807-815, 2012.

Mondal, T.K., Ganie, S.A., Debnath, A.B.: Identification of novel and conserved miRNAs from extreme halophyte, Oryza coarctata, a wild relative of rice. - PloS ONE 10: e0140675, 2015.

Mondal, T.K., Rawal, H.C., Chowrasia, S., Varshney, D., Panda, A.K., Mazumdar, A., Kaur, H., Gaikwad, K., Sharma, T.R., Singh, N.K.: Draft genome sequence of first monocothalophytic species Oryza coarctata reveals stress-specific genes. - Sci. Rep. 8: 13698, 2018.

Pfaffl, M.W.: A new mathematical model for relative quantification in real-time RT-PCR. - Nucl. Acids Res. 29: $45-51,2001$

Pfaffl, M.W., Tichopad, A., Prgomet, C., Neuvians, T.P.: Determination of stable housekeeping genes, differentially regulated target genes and sample integrity: BestKeeper-
Excel-based tool using pairwise correlations. - Biotechnol. Lett. 26: 509-515, 2004.

Sakuma, Y., Maruyama, K., Osakabe, Y., Qin, F., Seki, M., Shinozaki, K., Yamaguchi-Shinozaki, K.: Functional analysis of an Arabidopsis transcription factor, DREB2A, involved in drought-responsive gene expression. - Plant Cell 18: 12921309,2006

Schmittgen, T.D., Livak, K.J.: Analyzing real-time PCR data by the comparative C-T method. - Nature Protoc. 3: 1101-1108, 2008.

Shivhare, R., Lata, C.: Selection of suitable reference genes for assessing gene expression in pearl millet under different abiotic stresses and their combinations. - Sci. Rep. 6: 23036 , 2016.

Sengupta, S., Majumder, A.L.: Insight into the salt tolerance factors of a wild halophytic rice, Porteresia coarctata: a physiological and proteomic approach. - Planta 229: 911-929, 2009.

Silver, N., Best, S., Jiang, J., Thein, S.L.: Selection of housekeeping genes for gene expression studies in human reticulocytes using real-time PCR. - BMC Mol. Biol. 7: 3342, 2006.

Singh, V., Kaul, S.C., Wadhwa, R., Pati, P.K.: Evaluation and selection of candidate reference genes for normalization of quantitative RT-PCR in Withania somnifera (L.) Dunal. - PloS ONE 10: e0118860, 2015.

Thomson, M.J., De Ocampo, M., Egdane, J., Rahman, M.A., Sajise, A.G., Adorada, D.L., Tumimbang-Raiz, E., Blumwald, E., Seraj, Z.I., Singh, R.K., Gregorio, G.B.: Characterizing the Saltol quantitative trait locus for salinity tolerance in rice. Rice 3: 148-160, 2010.

Udvardi, M.K., Czechowski, T., Scheible, W.R.: Eleven golden rules of quantitative RT-PCR. - Plant Cell 20: 1736-1737, 2008.

Vandesompele, J., De Preter, K., Pattyn, F., Poppe, B., Van Roy, N., De Paepe, A., Speleman, F.: Accurate normalization of real-time quantitative RT-PCR data by geometric averaging of multiple internal control genes. - Genome Biol. 3: 1-12, 2002.

Wang, C., Cui, H.M., Huang, T.H., Liu, T.K., Hou, X.L., Li, Y.: Identification and validation of reference genes for RT-qPCR analysis in non-heading Chinese Cabbage flowers. - Front. Plant Sci. 7: 811, 2016.

Wu, Z.J., Tian, C., Jiang, Q., Li, X.H., Zhuang, J.: Selection of suitable reference genes for qRT-PCR normalization during leaf development and hormonal stimuli in tea plant (Camellia sinensis). - Sci. Rep. 6: 19748, 2016. 